\title{
İslamiyet ve Kudüs
}

\section{Ömer Faruk HARMAN*}

\section{Islam and Jerusalem}

Citation/@: Harman, Ömer Faruk, (2019). Islam and Jerusalem, Milel ve Nihal, 16 (1), 9-30.

Abstract: In this article it is dealt with the place and importance of Jerusalem in Islam and what it means from the viewpoint of Muslims. As is known, Jews, Christians and Muslims dominated the Jerusalem in different times throughout history and Jerusalem witnessed the significant struggles. Every religion has some important and holy places. We can refer to some points which make Jerusalem important for Muslims. For example, it is addressed to Masjid al Aqsa in Qur'an, we have some hadiths concerning to the subject, and Jerusalem is the first Qibla of Muslims. In this study, we will firstly make some explanations about holiness thought of Islam and the source of Jerusalem's holiness for Muslims. Then moving from verses and hadiths we will point out where Masjid al Aqsa is and debates about it.

Keywords: Islam, Jerusalem, Holiness, Prophet David, Isra Surah.

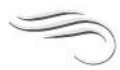

Atıf/C: Harman, Ömer Faruk, (2019). İslamiyet ve Kudüs, Milel ve Nihal, 16 (1), 9-30.

Öz: Bu makalede Kudüs'ün İslam dinindeki yeri, önemi ve Müslümanlar açısından ne anlam ifade ettiği üzerinde durulmaktadır. Bilindiği üzere Kudüs, tarih boyunca çeşitli zamanlarda Yahudilerin, Hıristiyanların ve Müslümanların hakimiyetinde kalmış ve önemli mücadelelere sahne olmuştur. Her dinin önemli ve kutsal kabul edilen bazı mekanları bulunmaktadır. Kur'an'da Mescid-i Aksa'ya atıfta bulunulması, konuya ilişkin hadisler, Müslümanların ilk kıblesi olması gibi hususlar Kudüs'ü Müslümanlar açı-

* Prof. Dr., İbn Haldun Üniversitesi İslami İlimler Fakültesi, [ofaruk.harman@ihu.edu.tr]. 
sından önemli kılmaktadır. Bu çalışmada öncelikle İslam’ın kutsallık anlayışı ve Müslümanlar açısından Kudüs'ün kutsiyetinin kaynağı hakkında bilgi verilecek, ardından ayet ve hadislerden hareketle Mescid-i Aksa'nın neresi olduğu ve Mescid-i Aksa etrafındaki tartışmalara işaret edilecektir. Anahtar Kelimeler: İslam, Kudüs, Kutsalıı, Hz. Davud, İsra Suresi.

\section{Giriş}

Kutsal kavramı dinin temel unsurlarından biridir ve her dinde mutlaka kutsal alan mevcuttur. Dinler Tarihine göre uluhiyetin tecelli ve tezahür ettiği (hierophanie) mekan, zaman ve nesneler kutsallık vasfı kazanırlar. Dinimizde ve Kitabımızda mekanı, zamanı kutsal sayan ifadeler vardır. Kur'an-1 Kerim'de kutsallığ ifade eden üç temel kavram vardır ki, bunlar da $k d s$, brk ve $h r m$ köklerinden türeyen kavramlardir.

Kds kökünden gelen kutsiyet kavramı "kudüs, kuddûs, mukaddes, mukaddese" şekillerinde on ayette yer almaktadır. Genellikle Cibril diye anlaşılan ve dört ayette yer alan "rûhu'l-kudüs" tabiri üç yerde Hz. İsa'yı destekleyen melek, bir ayette de Kur'an'ı Allah'tan alıp getiren varlık olarak anlatılır (Bakara 2/87, 253; Mâide 5/110; Nahl 16/102). Bir ayette meleklerin Allah'1 tesbih ve takdis ettiği belirtilmiş (Bakara 2/30), iki ayette de Kuddûs ismi Allah'a izafe edilmiştir (Haşr 59/23; Cum’a 62/1). “Yaratılmışlık özelliklerinden ve mahiyetinin idrak edilmesinden münezzeh oluş manasında Allah'a izafe edilen bir kavram" diye tanımlanan ve Esmâ-i hüsnâdan biri olan Kuddûs, "Allah'ın yetkinliğin zıddı olan özelliklerden (nakâis) ve erdemliğin zıddını teşkil eden niteliklerden (uyûb) berî ve yüce tutulması" demektir. Kutsiyet kavramı çeşitli hadislerde de Allah'a izafe edilmiştir. Dinimize göre mutlak kutsal, Cenab-1 Hak'tır.

İki ayette, Allah'ın Hz. Mûsâ'ya hitabı esnasında Mûsâ'nın "mukaddes bir vadide" bulunduğunun kendisine bildirildiği ifade edilmekte (Tâhâ 20/12; Nâziât 79/16), bir ayette Hz. Mûsâ'nın kavmine hitaben, "Allah'ın size takdir ettiği mukaddes yere (arz-1 mukaddese) girin" dediği belirtilmektedir (Mâide 5/21).

Taberî, vadinin mukaddes oluşunu manevi kirlerden temizlenip mübarek olmakla açıklamıştır. ${ }^{1}$ Mâtürîdî ise üzerinde Allah'tan başkasına tapınılmamış yer özelliği taşıması veya Kâbe'de ve diğer camilerde olduğu gibi içinde ibadet edilmesinin sevabının fazla olması şeklinde yorumlamış, İsrâ suresinin 1. ayetine atıfta bulunup

1 Taberi, Câmiu'l-beyân, c. VI, s. 234; c. XVI, s. 182.

10 
(17/1) çevre olarak "meyveli ve bereketli" anlamına gelebileceği gibi "şirkten ve her çeşit kötülükten uzak tutulmuş âbid ve zâhidlerin bulunduğu yer" olarak da anlaşılabileceğini belirtmiştir. ${ }^{2}$ Takdisi "Allah'ın kişiyi mânevî kirlerden temizleyip arındırması" manasına alan Râgıb el-İsfahânî, maddî mekânların kutsiyetini "en büyük kirlilik olan şirkten temiz ve uzak tutulması" şeklinde açıklamıştır. ${ }^{3}$

Brk kökünden türeyen "bâreknâ, mübarek, mübareke" kelimeleri de yine aynı anlamda üstün ve mübarek olmayı ifade ederler. "Mübarek kıldık" anlamındaki "bâreknâ" kelimesi A'raf 7/137; İsra 17/1; Enbiya 21/71, 81; Saffât 37/113; Sebe 34/18' de Filistin coğrafyas1 ve Mescid-i Aksa için kullanılmaktadır. Yalnızca "mübarek" sıfatı da Kur'ân-1 Kerim için (Enam 6/92, 155; Enbiya 21/50; Sâd 38/29), Kabe için (Al-i İmran 3/96); Hz. İsa için (Meryem 19/31); Zeytin ağac1 için (Nur 24/35); Musa'ya vahyin geldiği mekan için (Kasas 28/30); yağmur için (Kaf 50/9) ve Kur'ân'ın inzal edildiği gece için (Duhan 44/3) kullanılmıştır.

Hrm kökünden gelen "Haram" da hürmeti gerektiren, bazı şeylerin yapılması yasak olan yer anlaminda ve Mescid-i Haram (Bakara 2/144) olarak Kur'an'da yer almaktadır.

Görüldüğü gibi mekanlar ve zamanlar için mukaddes ve mübarek nitelemeleri kullanılmaktadır. Bu mekan ve zamanlara kutsiyet kazandıran, o mekan ve zamanlarda ilahi kelamın vahyedilmiş olmasıdır. Bir diğer ifadeyle kutsal mekanlar taşı ve toprağı farklı olduğu için değil, ilahi vahyin tecelli ettiği mekan ve zaman oldukları için mukaddestir.

Kur'an'da da beyan edildiği üzere Hz. Nuh'tan itibaren bütün peygamberler, Allah'tan başkasına kutsiyet atfedip ubudiyette bulunmamaları konusunda ümmetlerini uyarmış, her peygamberin davetinin temel ilkesini tevhid inancı oluşturmuştur. Çünkü Allah'tan başka herhangi bir varlığa kutsiyet kapsamında gönül bağlamak, yaratılanların en şereflisi olan insanın hem selim fitratıyla, hem şuurlu canlı olmanın sağladığı üstün konumuyla, hem de şahsiyetinin gelişmesi olgusuyla bağdaşmaz. ${ }^{4}$

2 Matüridi, Tevîlâtü'l-Ķur'ân, vr. 181b; 457b.

3 Ragib el-Isfahani, "k̦ds" el-Müfredât.

4 Günay Haral, "Kutsiyet (İslam'da)", DİA, (Ankara: TDV Yayınları, 2002), c. 26, s. 497. 


\section{Müslümanlara Göre Kudüs'ün Kutsiyeti}

Bilindiği gibi Kudüs şehri Müslümanlar açısından mukaddes bir yerdir. Bütün peygamberlere iman, Müslüman olmanın ön şartı olduğundan, Kudüs'ü fetheden Hz. Davud, orada mabed yapan Hz. Süleyman, Kudüs mabedinde görev yapan Hz. Zekeriya, Hz. Yahya, peygamberimizin "biraderim" dediği ve Kudüs'te doğup Kur'an'da "Arz-1 Mukaddese" diye nitelendirilen Filistin bölgesinde tebliğ faaliyetinde bulunan $\mathrm{Hz}$. İsa ve yolu o bölgeye ve $\mathrm{Ku}$ düs'e uğrayan diğer peygamberler, bütün Müslümanların, "Biz Allah'ın elçileri arasında ayırım yapmayız" dedikleri (Bakara 2/285) mümtaz şahsiyetlerdir. Diğer taraftan Hatemu'l-Enbiya olan $\mathrm{Hz}$. Muhammed'in ve Müslümanların ilk kıblesi olan, İsra mucizesinin varış noktası kabul edilen Kudüs ve bütün bu peygamberler aracılığıyla ilahi vahyin tecelli ettiği bu topraklar, Kur'an'da "Arz-1 mukaddese" diye tavsif edildiği için biz Müslümanlarca da mübarektir.

\section{A. Kur'an'da Kudüs}

Kur'an-1 Kerim'de şehir adı olarak Kudüs geçmemektedir. Her ne kadar Kur'an'da Arapça kds kökünden gelen "Kuddûs, kudüs, mukaddes, mukaddese" kelimeleri yer almakta ise de bunlardan "kudüs" kelimesi, şehir adı olmayıp, "Ruhu'l-kudüs" şeklinde kullanılarak Cebrail'i ifade etmektedir.

Kur'an'da şehir adı olarak Kudüs kelimesi geçmese de yorumlamaya müsait, tarihi veya bağlam olarak, dolaylı veya doğrudan Kudüs'e işaret ettiği kabul edilen ayetler vardır. Bu tür referansların 21 surede 70 kadar olduğu ileri sürülmektedir. ${ }^{5}$ Bu ayetlerin bazılarının Kudüs şehrine referansta bulundukları uzak bir ihtimal olsa da, bazılarının ise Kudüs'e işaret ettikleri açıtır. Bu referansları şu şekilde gruplandırabiliriz:

\section{Kudüs'e İşaret Eden Mekanla İlgili Ayetler}

Kur'an'da mekanla ilgili olarak “Arz-1 mukaddese, Bük'atü'l- mübareke, el-arz elletî bâreknâ" kavramları geçmektedir (Maide 5/21; Araf 7/137; Enbiya 21/71, 81; Sebe 34/18). Bu ayetlere bakıldığında Kur'an, "mukaddes diyar" in özel yerini belirtmemekte, fakat tarihi

5 Abdallah el-Khatib, "Jerusalem in the Qur'an", British Journal of Middle Eastern Studies, 2001, sayı: 28/1, s. 35 
gerçekler nazar-1 dikkate alındığında gerek İsrailoğullarından, girmeleri emredilen yerin (Maide 5/21), gerekse Firavun'un zulmünden kurtarılıp yerleştirildikleri bereketli toprakların Filistin olduğu görülmektedir. Öte yandan İsra suresinde (17/1) Mescid-i Aksa ve çevresinin mübarek oluşu açıkça ifade edilmektedir. Eğer buradaki "el-Mescidü'l-Aksa"dan maksat Kudüs ise, o takdirde Kudüs, mukaddes beldenin (arz-1 mukaddese) asıl ve önemli kısmıdır.

\section{a. Arz-1 Mukaddese}

Alimler, Maide 5/21' de yer alan arz-1 mukaddese'nin ve Maide 5/22$24,26^{\prime}$ da bahis konusu edilen yerin Kudüs ve çevresi olduğuna kaildirler. Ayette (Hz. Musa şöyle dedi): "Ey kavmim, Allah'ın size vaat ettiği "mukaddes topraklara" girip yerleşin ama sakın (orada yaşayan kavimden korkarak) geri dönmeyin. Aksi halde hüsrana uğrarsınız" (Maide 5/21) denilmektedir. Taberi, Ebu Leys es-Semerkandi, Maverdi, Nesefi, Kurtubi ve başkaları bu ayetteki ve onu takip eden 5/22-24, 26 ayetlerdeki kutsal toprağı Filistin coğrafyası ve Kudüs olarak yorumlamaktadırlar.

\section{b. Meşâriku'1-Arz ve Meğâribuhâ Elletî Bâraknâ Fîhâ}

Araf suresinde "Hor görülüp ezilmekte olan o kavmi de içini bereketle doldurduğumuz yerin doğu taraflarına ve batı taraflarına mirasçı kıldık..." (7/137) buyrulmaktadır. Ayetteki yerin doğuları ve batılarından kasıt Taberi, Maverdi, Kurtubi ve Razi gibi müfessirlere göre Bilâdü'ş-Şâm'dır ki, Kudüs de bu bölgenin en önemli bölgesidir.

\section{c. Mübevvee Sidk}

“And olsun biz İsrail oğullarını güzel bir yurda yerleştirdik ve onlara temiz nimetlerden rizıklar verdik..."(Yunus 10/93) ayetinde bahsedilen "güzel, temiz yer" bazı müfessirlerce Kudüs, bazılarınca da Bilâdü'ş-Şâm olarak yorumlanmıştır.

\section{d. Karye}

Kur'an'da geçen "karye" kelimesinin, kimi zaman Kudüs'e işaret ettiği ifade edilmektedir. "İsrailoğullarına, bu kasabaya girin, orada bulunanlardan dilediğiniz şekilde bol bol yiyin. Oraya saygılı bir şekilde girin ve Rabbimiz! Dileğimiz isyanımızın affıdır deyin ki biz de sizin günahlarınızı bağışlayalım..." (Bakara 2/58). Süddi, Katade, Rebi b. Enes ve Ebu Muslim el-Esfahani bu ayetteki karyenin Kudüs olduğu kanaatindedirler. İbn Abbas ve Ebu Zeyd karyenin Eriha ol- 
duğunu söylemekteyken, Razi ve İbn Kesir ise ilk görüşü savunanalar arasındadır. Muhammed Esed de ayetteki karyeden maksadın Filistin olduğunu belirtmektedir. ${ }^{6}$

\section{2. İbadet Yerini İfade Eden ve Kudüs'ü İşaret Eden Ayetler}

\section{a. Mescid}

"Eğer iyilik ederseniz kendinize etmiş, kötülük ederseniz yine kendinize etmiş olursunuz. Nihayet diğer fesatçlığınızı cezalandırma vakti gelip çatınca, düşmanlarınız tarafından şeref ve itibarınız ayaklar altına alındı. İlkinde olduğu gibi düşmanlarınız yine mabedinize (mescid) girdiler, her yeri yakıp yıkıp talan ettiler" (İsra 17/7) ayetinde yer alan mescid, Kudüs'teki Süleyman mabedidir7. Genel kabule göre bu ayet, Romalı komutan (sonradan kral) Titus'un, MS. 70 yılında Kudüs'ü ve Süleyman mabedini (Beit ha-Mikdaş) yakıp yıkmasına işarettir.

\section{b. Kıble}

Bilindiği gibi Müslümanların namaz için yöneldiği ilk kıble Kudüs'tür. Hicretten sonra birbirini takip eden 17 ay, Bakara 2/142-146 ayetlerin vahyi ile kıble değiştirilene kadar Müslümanların namazda iken Beytülmakdis'e doğru yüzlerini döndükleri bilinmektedir. Kudüs şehri bu özelliğinden dolayı da İslâm'da ayrı bir öneme sahiptir. Buhari ve Müslim'in rivayet ettiklerine göre Bera b. Azib (ra) şöyle söylemiştir:

'Resulullah (sav) Beyt-i Makdis (Mescid-i Aksa) tarafına on altı ya da on yedi ay namaz kıldı. Resulullah (sav) Kabe tarafına namaz kılmayı arzuluyordu. Yüce Allah da şu ayeti kerimeyi indirdi: 'Yüzünü göğe doğru çevirip durmanı görüyoruz. Seni hoşnut kalacağın kıbleye doğru yönelteceğiz. Artık yüzünü Mescid-i Haram tarafına çevir. Ve her nerede olursanız olun yüzünüzü onun tarafına çevirin. ${ }^{8}$

Bunu te'yid eden daha birçok hadisi şerif rivayet edilmiştir. ${ }^{9}$

6 Muhammed Esed, Kur'an Mesajı, (İstanbul: İşaret Yayınları, 2017), s. 62, dipn. 42.

7 Bkz., Ebu'l-Leys es-Semerkandi, Tefsiru'l-Kur'ani'l-Kerim Bahri'l-'Ulum, c. 2, s. 302; en-Nesefi, Medariku't-Tenzil, c. 3, s. 44; İbn Abdi's-Selam, Tefsiru'l-Kur'an, c. 2, s. 2I3; İbn Kesir, Tefsiru'l-Kur'an, c. 3, s. 494; Ebu'l-Ferac 'Abdu'r-Rahman 'Ali b. Muhammed el-Cevzi, Zadu'l-Mesir fi Ilmi't-Tefsir, c. 5, (Beyrut: el-Mektebu'lİslami' 1984), s. 11.

8 Bakara, 2/144.

9 Buhari, Salât 31; Müslim, Mesâcid, 2. 


\section{c. Mihrab}

Mihrab kelimesi mabed veya oda anlamındadır. Cami ve mescidlerin ön tarafında imamın duracağı yerin adı olmakla beraber, zikr-i cüz, irade-i kül yoluyla mabed ve mescide de mihrab denilmiştir. Kur'an'da "Zekeriya mabede her uğradığında Meryem'in yanında yiyecek bulunduğuna tanık olurdu"...(Al-i İmran 3/37); "Mabette dua ve ibadetle meşgul olduğu sırada melekler ona şöyle seslendiler...(Al-i İmran 3/,39); “Vaktiyle o iki kişi mabedin duvarına tırmanıp aniden Davud'un huzuruna çıkıverdiler...(Sâd 38/21) ayetlerinde yer alan bu mihrablar Müslüman coğrafyacılar açısından Kudüs'teki mabede işaret etmektedir. ${ }^{10}$

\section{Sembolik Olarak Kudüs'ü İşaret Eden Ayetler}

Tin suresinde yer alan "İncire, zeytine, Sina dağına ve bu güvenilir beldeye yemin olsun ki" (Tin 95/1) ayetindeki zeytinin sembolik yorumlarında; zeytinin Kudüs'teki Zeytin Dağı'na, Kudüs'teki Mescid-i Aksa'ya veya Beytülmakdis'e (Kudüs) işaret olduğu rivayet edilmektedir.

\section{Kudüs'ü de İçine Alan Mukaddes Belde'de Yaşamış Halk ve Peygamberlerin Kıssalarının Anlatıldığı Ayetler}

\section{a. Hz. İbrahim}

“Biz onu ve yanında bulunan yeğeni Lut'u kurtarıp, herkes için bereketli kıldığımız topraklara (Filistin) ulaştırdık" (Enbiya 21/71).

\section{b. Hz. Davud ve Hz. Süleyman}

Hz. Davud, krallığının 33 yılını, oğlu Süleyman da krallığının 40 yılını Kudüs merkezli bölgede geçirmiştir.

\section{c. Hz. İsa ve Hz. Meryem}

Hz. Meryem'in annesi tarafından mabede (Kudüs'teki Süleyman Mabedine) adanması ve mabedde görevli Hz. Zekeriya'nın onun bakımıyla yükümlü tutulması (Al-i İmran 3/35-47); Hz. İsa'nın, Kudüs'te dünyaya gelmesi ve Kudüslüler tarafından sorguya çekilmesi, onun da "Allah'ın kulu olduğunu, kendisine kitap verileceğini ve peygamber olarak seçileceğini bildirmesi (Meryem 19/22-33), bu

\footnotetext{
10 Abdallah Khatib, "Kur'an'da Kudüs", çev.: Ramazan Işık, FÜİFD, 2004, sayı: 9/1, s.132.
} 
peygamberlerin ve Hz. Meryem'in Kudüs ile olan bağlantılarını ortaya koymaktadır.

Diğer taraftan İslam gelmeden evvel Kudüs'te meydana gelen olaylar kapsamında Kudüs'ün tahribi olayı (İsra 17/4-7), İslam'ın gelişinden sonra ise İsra mucizesi (İsra 17/1), ayrıca kıblenin tahvili olayı (Bakara 2/142-150) ve Bizans'ın mağlup olması ve bölgenin Perslerin eline geçmesi meselesi (Rum 30/1-3) hep o bölgelere işaret etmektedir.

\section{Mescid-i Aksa}

Kur'an'daki el-Mescidü'l-Aksa'nın neresi olduğu konusunda ulema arasında fikir ayrılığı olmakla beraber, İsra 17/1'deki “el-Mescidu'1Aksa"nın Kudüs'e işaret ettiği konusunda neredeyse İslam alimlerinin tamamı hem fikirdirler:

"Bir gece, kendisine ayetlerimizden bir kısmını gösterelim diye kulunu Mescid-i Haram'dan, çevresini mübarek kıldı̆̆ımız Mescid-i Aksa'ya götüren Allah noksan sıfatlardan münezzehtir" (17/1).

Razi bu ayeti şöyle yorumlamaktadır:

'Büyük tefsirciler buradaki Mescid-i Aksa'nın Kudüs'teki kutsal mabed anlamina geldiğinde hem fikirdirler. Onlar ittifakla ayette zikredilen mescidin Kudüs'teki mescide işaret ettiğini kabul etmektedirler. ${ }^{11}$

Hz. Ömer, (16/637) yılında şehri fethettiğinde, Kudüs patriği Sophronius ona Mescid-i Aksa'yı göstermiş, caminin yerini gören Hz. Ömer ise "Bu yer, tam olarak peygamberin bize tanımladığı yerdir" diyerek bu yerin temizlenmesini ve restore edilmesini emretmiştir. ${ }^{12}$

Diğer taraftan Hz. Peygamberden gelen rivayetlere bakıld1ğında Kudüs'teki mescidden bahseden hadislerde genel olarak "Mescid-i Aksa" değil "Beytülmakdis" adı kullanılmaktadır. "Mescid-i Aksa" olarak kullanımı çok azdır. ${ }^{13} \mathrm{O}$ kadar ilginçtir ki Miraçtan bahseden hadislerde ${ }^{14}$ ve benzer rivayetlerde ${ }^{15}$ dahi burasi

11 Razi, et-Tefsiru'l-Kebir, (Kahire 1938), c. 20, s. 146.

12 Muciru'd-Din el-Hanbeli, Tarihu'l-Kuds ve'l-Halil, c. 1, s. 256.

13 Mescid-i Aksa ve Beytü'l-Makdis kelimelerinin hadislerdeki kullanımı için bk. Wensick, Concordance, c. 8, s. 305, 333.

14 İbn Sa'd, I, s. 215.

15 Belazuri, I, s. 296 
“Mescid-i Aksa” olarak değil de "Beytülmakdis" olarak nitelendirilmektedir. ${ }^{16}$

\section{B. Hadis Literatüründe Kudüs}

Kudüs'ü yücelten ve öven birçok hadis vardır. Bu hadisler, Kütübü's-Sitte gibi ilk dönem hadis külliyatında ve Vakidi (ö. 207/823)'nin Fütuhu Biladi'ş-Şam'1 gibi ilk dönem İslam tarihi kitaplarında bulunabilir. Ayrıca, Kudüs'ün faziletine dair ihtisas kitapları da mevcuttur. Kudüs'ün fazileti ile ilgili olarak sadece üç hadisi zikretmek yeterli olacaktır. Bu hadisler genel olarak Müslüman hadisçiler tarafından sahih hadisler olarak kabul edilmektedir.

\section{1. Üç Mescid Hadisi}

Üç mescid hadisi Kudüs'ün fazileti ile ilgili olarak en meşhur hadistir.

Resulullah (a.s.) şöyle buyurmuştur: '(İbadet için) Yolculuk ancak şu üç mescidden birine olur: Benim şu mescidime, Mescidi Haram'a ve Mescidi Aksa'ya".

Burada kastedilen yolculuk, ibadet kastıyla olan özel yolculuktur. Bu hadisi şerif dolayısıyla Mescid-i Aksa, harem mescidlerin üçüncüsü sayılmıştır. ${ }^{17}$

Goldziher, Zühri'nin Emeviler lehine hadis uydurduğuna örnek olarak bu hadisi göstermektedir. Buna göre "Mescid-i Haram, benim mescidim (Mescid-i Nebevi) ve Beytülmakdis olmak üzere üç mescid için seyahat yapılır"18 mealindeki hadis, siyasi gayelerle uydurulmuştur. Emevi halifesi Abdülmelik b. Mervan (ö.86/705), Mekke'de hüküm süren Abdullah b. Zübeyr'in Mekke'ye gidecek olan Suriyelilerden biat alabileceğini düşünerek hacca gitmeyi yasaklamıştır. Karşı bir tedbir olarak haccı Kudüs'teki Kubbetü'sSahra'ya çevirmenin çarelerini aramış ve Kabe etrafında yapılan tavafla Kudüs'ün mukaddes mekanında yapılacak tavafın şer'an aynı derecede makbul sayılabileceğine dair bir karar çıkartmıştır. Zühri

\footnotetext{
16 İbn İshak, Sire, (Konya 1981), s. 463.

17 Buhari, Fazlu's-Salât, 1; Müslim, Hac, 95; Ebu Davud, Menâsik, 98; Darimi, en-Nesai, II, 37; Ahmed b. Hanbel, Müsned, II, 134; İbn Mace, İkâmetü's-Salât, 196; ve İmam Malik tarafından temel hadis kitaplarında zikredilir. Bkz, A. J. Wensinck, Concordance et Indices de la Tradition Musulmane, Tome 2, (Leiden, E. J. Brill, 1943), s. 234; İbn Hacer el-Askalani, Fethu'l-Bari, c. 4, s.10 1; bk: M. Lecker, 'Biographical Notes on İbn Shihab ez-Zühri', Journal of Semitic Studies, 1996, sayı: 41, s. 42.

Buhari, Savm, 67; Sayd, 26; Müslim, Hac, 415, 511, 512; Nesai, Mesacid, 10.
} 
de bir hadis uydurarak siyasi sebeplerin gerektirdiği bu reformu haklı çıkarma görevini üstlenmiştir. Buna göre haccın Mekke, Medine ve Kudüs'te olmak üzere makbul olduğu üç mescid vardır. ${ }^{19}$

Goldziher'in bu iddiası doğru değildir çünkü hadisin uydurucusu olarak gösterilen Zühri'nin bu işte bir rolünün olması tarih bakımından mümkün değildir. Zira kaynaklar Zühri'nin, Abdülmelik b. Mervan ile görüşmesinin (81-84/700-703) yılları arasında gerçekleştiğini belirtmektedir. Buna göre Zühri'nin halife ile görüşmesi, Abdullah b. Zübeyr'in öldürülmesinden çok sonradır.

Kubbetü's-Sahra'nin inşasına (66/685-686) yılında başlanmış, inşa (72/691)'de tamamlanmıştır. Söz konusu olay bu tarihlerde meydana gelmişse 50 veya 58 yılında doğduğu kaydedilen Zühri, o esnada 14 veya 22 yaşlarında olmalıdır. Bu durumda halifenin, böylesine önemli bir karar için, İslam dünyasında tanınmayan genç birini tercih etmesi makul görülmemektedir. Diğer taraftan sözü edilen hadis, sahabeden Hz. Ali, Abdullah b. Amr, Ebu Said elHudri, Ebu Hureyre gibi kişiler tarafından da rivayet edilmiştir. ${ }^{20}$

\section{Mescid-i Aksa'nın İnşa Edilen İkinci Mescid Oluşu}

Ebu Zer el-Gıfari'den rivayet edildiğine göre, o şöyle dedi:

"Yeryüzünde inşa edilen ilk mescidin hangi mescid olduğunu peygambere sordum? Peygamber cevap verdi: Yeryüzünde inşa edilen ilk mescid, Mekke'deki Mescidi Haramdır. Ondan sonra hangisi inşa edildi diye sordum? Peygamber Mescidi Aksa diye cevap verdi. Sonra bu ikisi arasında kaç yıl vardır diye sordum? Peygamber 40 yıl diye cevap verdi21 ve ilave etti: Nerede namaz vaktine ulaşırsan orada namazını kıl, orası mescittir." 22

Goldziher, Muslim Studies, II, ss. 44-45.

Ahmet Yücel, Oryantalist Hadis anlayışı ve Eleştirisi, (İstanbul 2015), ss. 136-137; Ebu Şehbe, Sünnet Müdafaası, çev.: M. Görmez, M. Emin Özafşar, (Ankara 1990), II, 83; A. Örenç, “Kudüs ve Mescid-i Aksa'nın Faziletine Dair Hadisler ve Yorumu", Türk-İslam Medeniyeti Akademik Araştırmalar Dergisi, 2016, say1: 22, ss. 141143.

Buhari, Enbiya, 10,12, 40; Müslim, Mesâcid, 1,2.

Abdu'r-rezzâk, el-Musannef, I, 403 (no: 1578), III, 348 (no: 5925); Buhârî, Ehâdîsü'lEnbiyâ', 40; Müslim, Ebü'1 Hüseyn b. Haccâc, Sahîhu Müslim, Riyad, 1998, Mesâcid, 1, 2. Benzer ifadeler için bkz. Malik b. Enes, Muvatta, thk.: Muhammed Mustafa el-A'zamî, (yy, 2004), c. I, s. 266 (no: 360); Ahmed b. Hanbel, Müsned, thk.: Şu'ayb Arnavut-Adil Mürşid, (Beyrut, 1995), c. I, s. 309, V, 157; Buhârî,

18 


\section{Hz. Süleyman'a Dair Rivayet}

Ahmed b. Hanbel, Nesâi ve Hakim'in Abdullah b. Ömer (ra)'den rivayet etmiş oldukları bir hadisi şerife göre de Resulullah (sav) şöyle buyurmuştur:

'Süleymân (s) Mescidi Aksa'yı yaptığında Rabbinden üç şey istedi. Rabbi ona ikisini verdi. Ben üçüncüsünü de vermiş olmasını ümit ediyorum: Kendisine, kendi hükmüne denk gelecek hüküm vermesini istedi, (Rabbi) bu istediğini verdi. Kendisinden sonra hiç kimsenin ulaşamayacağ ${ }_{1}$ bir saltanat vermesini istedi, bu istediğini de verdi. Bir de her kim, bu Mescid'de -yani Mescidi Aksa'da- namaz kılmak amacıyla evinden çıkarsa anasından doğmuş gibi günahlarından sıyrılsın istedi. Biz Allah'ın bu istediğini de ona vermiş olmasını ümit ediyoruz. ${ }^{23}$

\section{Kandillerine Yağ Gönderilmesi}

Bir hadis-i şerifte bildirildiğine göre Resulullah (sav)'ın câriyesi Meymune (ra):

'Ey Resulullah! Bize Mescidi Aksa hakkındaki hükmün ne olduğunu bildir' dedi. Resulullah (s.a.s.) da şöyle buyurdu: 'Oraya (Mescidi Aksa'ya) gidin ve içinde namaz kılın.' -Hadisin râvisi dedi ki: 'O zaman burası Dâru'l-Harb'di (yani Müslüman olmayanların hâkimiyeti altındaydı).'- (Resulullah (sav) sözlerine daha sonra şöyle devam etti): 'Eğer oraya gidemez ve içinde namaz kılamazsanız kandillerinde yakılmak üzere oraya zeytinyağı gönderin. ${ }^{24}$

\section{Mescid-i Aksa'da Kılınan Namazın Sevabı}

Hadislerde, Mescid-i Aksa'da kılınan namazın sevabının kat kat olduğuna dair rivayetler de vardır. ${ }^{25}$

\section{Mescid-i Aksa'nın Yeri}

Günümüzde Kubbetü's-Sahra'nın güney tarafında bulunan ve Mescid-i Aksa diye bilinen mescidin inşası Emevi Halifesi Abdülmelik b. Mervan'ın oğlu I. Velid (705-715) döneminde tamamlanmıştır.

Ehâdîsü'l-Enbiyấ', 10; İbn Mâce, Ebû Abdillah Muhammed b. Yezîd, Sünen, (İstanbul, 1981), Mesâcid, 7; Nesâî, Ahmed b. Şu'ayb, Sünen, thk.: Abdu'l-Fettah Ebû Ğudde, (Haleb, 1986), Mesâcid, 3.

23 Ahmed ibn Hanbel, Müsned, II, 176; Nesâi, Sünen, II, 34; İbn Mâce, İkâme, 196.

24 Ebu Davud, Kitâbu's-Salât, 14.

25 Örenç, "Kudüs ve Mescid-i Aksa'nın Faziletine Dair Hadisler”, ss. 144-146. 
Kur'an-1 Kerim'de "el-Mescidü'l-Aksa" adının geçtiği ayetin (İsra 17/1) nüzulünden çok sonra inşa edilen Kudüs'teki mescide "Mescid-i Aksa" adı verilmiştir. ${ }^{26}$

\section{1. İsra Suresinin Nüzul Tarihi}

İsra suresinin ne zaman nazil olduğu konusunda ihtilaf vardır. Genelde surenin Mekkî olduğu kabul edilmektedir. Nüzul sıralamasinda 50. sure olduğu ve Kasas suresinden sonra, Yunus suresinden önce indiği belirtilmektedir. ${ }^{27}$ "İlk ayetinde sözü geçen sırlarla dolu 'gece yolculuğu' bu surenin, daha önce değil, olsa olsa hicretten önceki yıl içinde vahyedilmiş olduğunu göstermektedir. Suyûtî, nüzul sıralamasinda sureyi 28. sure (Kasas) ile 10-12. sureler grubu arasina yerleştirmektedir. Bir kısım otoriteler, surenin bazı ayetlerinin çok daha sonraki bir zamana, yani Medine dönemine ait olduğu görüşünü ileri sürmüşlerse de ${ }^{28}$ bu görüş, sadece tahminlere dayalı olduğundan pek makul görünmemektedir. ${ }^{29}$ İsra suresi Mekke döneminde indirilen son surelerden biri olup, Kasas suresinden sonra nazil olmuştur. ${ }^{30}$

Bir başka yoruma göre muhteva açısından dikkatli bir tahlil, İsra suresinin 2-39 ayetlerinin Medine döneminde nazil olduğu ihtimalini güçlendirmektedir. Çünkü İsra 2-3 ayetleri, Hz. Musa ve İsrailoğullarından bahsetmektedir. Devaminda İsrailoğullarına, geçmişlerinde başlarına gelen iki sürgün olayı hatırlatılmaktadır (İsra 17/3-8).

Bilindiği gibi Mekke'de yukarıdaki ayetlere muhatap olacak hiçbir Yahudi yoktu. Oysaki Medine'de Yahudiler çok etkili topluluk oluşturuyorlardı. Bu durum, yukarıdaki ayetlerin Medine'de nazil olduğu tezini güçlendirmektedir. Surenin devamında, Kur'ânî davetin esasları verildikten sonra (8-21. ayetler), Tevrat'ın “On Emir"ine benzer ilahi emirlerin sıralanması da (22-39. ayetler), bu ayetlerin Yahudi bir topluluğu muhatap aldığ 1 görüşüne kuvvet kazandırmaktadır. İsra suresi 2-39. ayetlerinin Medine'de nazil olduğu

\footnotetext{
26 Nebi Bozkurt, "Mescid-i Aksa”, DİA, c. 29, s. 270.

27 M. Öztürk, Kur'an-ı Kerim Meali, (Ankara 2015), s. 323.

28 Elmalılı, Hak Dini Kur'an Dili, c. 4, s. 3140.

29 Esed, Kur'an Mesajı, s. 558.

30 K. Yaşaroğlu, "İsra Suresi", DİA, 2001, c. 23, s. 177.
} 
görüşü bu kadar kuvvet kazanınca, ilk ayetinin de bu bağlamda Medine'de inmiş olması ihtimali kuvvet kazanmaktadır. ${ }^{31}$

\section{2. İsra Mucizesinin Zamanı}

Rivayetlerin genelinde olayın Mekke döneminde olduğu belirtilirse de bazıları vahyin ilk günlerinde olduğunu ${ }^{32}$, bazıları 5 . yılda veya 10. yıldaki Ebu Talib'in ölümünden sonra olduğunu iddia etmektedir. ${ }^{33}$ Belâzuri'ye göre İsra mucizesi hicretten bir yıl önce gerçekleşmiştir. ${ }^{34}$ Diğer taraftan İsra ve Mirac olayının aynı gecede mi yoksa farklı gecelerde mi olduğuna dair ihtilaf bulunmaktadır ${ }^{35}$.

\section{Mescid-i Aksa'nın Yeri}

İsra suresinde bildirilen İsra mucizesinin hicretten bir, bir buçuk yıl önce vuku bulduğu kabul edilmektedir. Gece yolculuğunun başlangıcı el-Mescidü'l-Haram, varış noktası da el-Mescidü'l-Aksa'dır. İsra mucizesinin başlangıç noktasında ihtilaf yoktur ancak varış noktası tartışmalıdır. Bu tartışmaları şu şekilde özetlemek mümkündür

(i) Ayette söz konusu edilen "el-Mescidü'l-Aksa" ne Kudüs'tür ne de Kudüs'teki bir yaprdir.

Bu görüşü savunanlara göre Kur'an-1 Kerim'de, "Rumlar (Bizanslılar), Arapların bulunduğu bölgeye en yakın bir yerde yenilgiye uğradılar" (Rum suresi 30/2-3) buyrularak, Kudüs'ün de içinde bulunduğu bölge, Arapların bulunduğu bölgeye en yakın bölge olarak tavsif edilmektedir. El-Mescidü'l-Aksa ise en uzak mescid demektir. Şu halde en yakın bölgede en uzak mescid olmaz.

(ii) İsra mucizesinin vuku bulduğu dönemde Kudüs'te "el-Mescidü'lAksa" diye bir yapr yoktur.

Kudüs, Yahudi Kutsal Kitabına göre ilk defa Hz. İbrahim kıssası çerçevesinde "Salem'in şehri" adıyla zikredilir. Daha sonra ise Hz. Davud'un şehri fethiyle beraber devletin siyasi merkezi, Hz. Süleyman'ın mabedi (Beit ha-Mikdaş=Beytülmakdis) inşa etmesiyle de dini merkez olur. Hz. Süleyman'ın inşa ettiği mabedin adı İbranice Beit ha-Mikdaş, Arapça Beytülmakdis'tir. Bu mabed, Yahudi

\footnotetext{
31 Hikmet Zeyveli, İlahi Dinlerde Mucize ve Gayb, (İstanbul: 2018,) ss. 69-74

32 Taberi, Tarihu'l-ümem ve'l-müluk, (Beyrut: 1995), c. I, s. 537

33 İbn Kesir, el-Bidaye ve'n-Nihaye, (Beyrut: 2005), c. II, s. 470

34 Belazuri, Ensabu'l-Eşraf, (Dımeşk: 1997), c. I, s. 295

35 Mehmet Azimli, “ İsra ve Mirac Olayları Üzerine Bazı Mülahazalar", Bilimname, 2009, say1: XVI/1, s. 44.
} 
Kutsal Kitabının naklettiğine göre, yedi yıllık bir inşaattan sonra, MÖ 960'da açılmış, MÖ 587'de Babillilerce yıkılmış, MÖ 515'te tekrar yapılmış, MÖ 20'lerde genişletilmiş, çevresine ihata duvarı çekilmiş, MS 70 yılında da ikinci ve son kez yıkılmıştır. İsra suresindeki 5. ayet, mabedin birinci yıkılışına, 7. ayet de ikinci yıkılışına telmih kabul edilmektedir.

MS 132' de Yahudilerin Roma'ya karşı ayaklanması, 135 yılında kanlı bir şekilde bastırılınca İmparator Hadrianus, şehri yeniden kurar, mabedin yerine ilah Jüpiter'e ithafen bir pagan tapınak yapar ve şehre "Colonia Aelia Capitolina" adını verir. Pagan Roma Hıristiyanlığa serbesti tanıyıp, bu yeni din yayılınca bu defa Hadrianus'un yaptırdığı pagan tapınak yıkılır ancak mabed, üçüncü kez tekrar yapılmaz. Çünkü İsa Mesih, mabedi göstererek "Size doğrusunu söyleyeyim, burada taş üstünde taş kalmayacak, hepsi yıkılacak" (Matta, 24:2) dediğinden, onun bu sözünü nakzetmemek için, yeni bir tapınak yapılmamıştır. Bizans İmparatorluğu döneminde Süleyman Mabedinin mekânında bina yoktu ve büyük kaya kütlesi açıkta idi. Hicret öncesinde İsra mucizesinin gerçekleştiği dönemde ve MS 637'de Hz. Ömer Kudüs'ü fethettiğinde orada yapı yoktu. Emevi Halifesi Abdülmelik b. Mervan, 690'lı yıllarda "Hacer-i Muallak" adı verilen kaya kütlesini örten "Kubbetü's-Sahra" yı yaptırdı. Daha sonra da "Mescid-i Aksa" da denilen kıble mescidini oğlu I. Velid, 705 'te tamamladi.

(iii) Yukarlda serdedilen sebeplere binaen, İsra suresindeki "el-Mescidü'lAksa", Kudüs'te değil semada, Sidretü'l-Münteha yakınında bir makamdir.

M. Hamidullah, Abdülmelik b. Mervan'ın Kudüs'te inşa ettirdiği mabede Mescid-i Aksa ismini verdiğine işaret ettikten sonra bu ismin giderek yaygın bir şekilde kullanıldığına dikkat çeker ve böylece kaynaklara da bu şekilde girdiğini belirtir. ${ }^{36}$

Hamidullah, İsra hadisesinin vuku bulduğu dönemde Kudüs'te herhangi bir mescidin bulunmadığına işaret ederek, ayetteki kavramın semada bulunan manevi mescidi işaret ettiğini ifade eder ve Hz. Peygamberin de Kudüs'e değil semadaki bu mescide götürüldüğünü söyler. ${ }^{37}$

36 M. Hamidullah, İslam Peygamberi, c. I, s. 141 (254 no'lu dipnot açıklaması).

37 M. Hamidullah, İslam Peygamberi, c. I, s. 140 (254 no'lu dipnot açıklaması). 
Hamidullah, Kur'an'da geçen" el-Mescidü'l-Aksa" terkibiyle siyer ve hadis metinlerinde yer alan "Mescid-i Aksa" kullanımı arasında dil bilgisi yönünden farklılık olduğuna dikkat çekerek, Kur'an'da zikredilen “el-Mescidü'l-Aksa"nın Kudüs'le bir ilgisinin olmadığını iddia eder. Onun açıklamalarına göre Kur'an'daki kullanımda sıfat-mevsuf ilişkisi varken, hadis metnindeki kullanımda muzaf-muzafun ileyh ilişkisi vardır. ${ }^{38}$ Hamidullah bu iddiasını dile getirirken Buhari'deki bir rivayette yer alan "Mescidü İlya" kavraminı referans gösterir ${ }^{39}$. Bu kavram Buhari'den daha mukaddem kaynak olan Abdürrezzak'ta da geçmektedir.40 Ona göre en erken dönem kaynaklarında ayetteki "el-Mescidü'1-Aksa” kavramı yer almayıp, "Mescidü İlya" kavramı kullanılmıştır. Bu nedenle ayetteki "el-Mescidü'l-Aksa" kavramının ve dolayısıyla da İsra hadisesinin Kudüs'le bir alakası yoktur ${ }^{41}$.

Batılı şarkiyatçılardan Wensinck de Emevi halifesi Abdülmelik tarafından Süleyman mabedinin bulunduğu harem bölgesine inşa edilmiş olan ve günümüzde "Mescid-i Aksa" olarak bilinen mescidin, Kur'an'da zikri geçen “el-Mescidü'l-Aksa” olmadığını söyler ve klasik müfessirlerin bunu miraçla ilgili rivayetlerle veya gökteki mescidle ilişkilendirdiklerini dile getirir. Ardından bu ismin yaygınlık kazanmasında Emevilerin, İslam'ın mukaddes şehirleri olan Mekke ve Medine'ye karşı Kudüs'ü ön plana çıkarma gayretlerinin etkili olduğunu söyler ${ }^{42}$.

(iv) "el-Mescidü'l-Aksa", Kudüs'te değil Ci'rane'dedir.

Alfred Guillaume, ayette geçen “el-Mescidü'l-Aksa”nın, Mekke yakınlarındaki Ci'rane' de bulunan mescid olduğunu söyler. ${ }^{43}$

Vakıdî (207/822) ve Ezrakî (224/839) gibi erken dönem kaynaklarında Mekke yakınlarındaki Ci'rane'de isrâ ayetinde geçen" elMescidü'l-Aksa" adında bir mescidin bulunduğuna dair sınırlı bir rivayet nakledilmiştir. Başta Guillaume olmak üzere Ateş, Bayram ve Azimli gibi son dönem araştırmacıları bu iki kaynakta yer alan

\footnotetext{
M. Hamidullah, İslam Peygamberi, c. I, ss. 140-141 (254 no'lu dipnot).

Buhari, Tefsir (İsrail), I.

Abdürrezzak, el-Musannef, c. 8, s. 455.

İsrafil Balcı, İsra ve Mirac Gerçeği, (Ankara 2012), s. 109.

A. J. Wensinck, "Mescidi Aksa", IA, c. 8, ss. 118-119.

Balc1, Issra ve Mirac Gerçeği, s. 113.
} 
aynı içerikteki rivayete dayalı olarak" el-Mescidü'l-Aksa"nın, Kudüs'te değil burada bulunduğunu ve dolayısıyla da İsrâ hadisesinin de sanıldığının aksine Kudüs'le değil Ci'râne'yle ilişkili olduğunu iddia etmişlerdir. ${ }^{44}$

Vakıdî'nin naklettiği rivayet 630 yılında yapılan Huneyn Savaşından sonra ganimetlerin taksimiyle ilgili haberler arasında yer almaktadır. Huneyn savaşında Hz. Peygamber ele geçirilen ganimetleri Mekke-Taif yolu üzerindeki Ci'râne' de muhafaza etmiş, savaş dönüşü on üç gün burada kalmış, kaldığı müddetçe, adı "elMescidü'l-Aksa" olan bir namazgahının olduğu, buna mukabil mezkur mescidin karşı tarafında da "el-Mescidü'l-Ednâ" adında ashabın namaz kıldığı bir başka mescidin bulunduğundan bahsetmektedir ${ }^{45}$. Ezrakî de burada iki ayrı mescidin olduğunu söyler ${ }^{46}$. Huneyn savaşı (8/630) yılında gerçekleşmiştir.

Bu iddia birkaç yönden tutarsız görünmektedir. Şöyle ki:

- Bu görüş kabul edildiği takdirde İsra suresinin ilk ayetlerinin, Huneyn savaşından sonra ve dolayısıyla Kur'an-1 Kerim'in Medine' de muhatap alacağı önemli bir Yahudi toplumunun artık mevcut bulunmadığı bir zamanda nazil olduğunu kabul etmemiz gerekecektir. Oysaki bu ayetler özellikle Yahudi bir kitleyi önemle muhatap almaktadırlar. Bu da en azından Medine'deki son Yahudi kabilesi Kureyzaoğullarının cezalandırıldıkları beşinci hicri yıldan önceki bir tarihe (Huneyn'den çok önceki bir tarihe)uygun düşmektedir. Dolayısıyla İsra ve Mescidu'l-Aksa kavramları Huneyn savaşından sonra vuku bulmuş olaylarla izah edilemez.

- Ezraki ve Vakıdi'nin zikrettikleri mescidin sıradan bir mescid olduğu, el-Aksa kelimesinin, aynı vadide bulunan, yakındaki ikinci bir mescidden (el-Mescidü'l-edna) ayırt edilmesi için bir niteleme olarak kullanıldığı anlaşılmaktadır.

- Bu mescidin çevresinin, ilgili ayetteki nitelemeyle "mübarek" olarak bilinmesi için önemli bir sebep görünmemektedir. ${ }^{47}$

44 Balcı, İsra ve Mirac Gerçeği, s.124.

45 Vakıdi, Kitabü'l-Meğazi, III, 958-959.

46 Ezraki, Ahbaru Mekke, II, 200.

47 Zeyveli, Ilahi Dinlerde Mucize ve Gayb, s. 83. 
(v) Mescid-i Aksa Kudüs'teki mescid midir?

Kudüs'teki mescid tarih, siret ve coğrafya kitaplarında hep "Beytülmakdis" diye anılmıştır. Bazı kaynaklarda ise "Mescid-i İlya" olarak geçmektedir.

Mescid-i Aksa'nın Kudüs'teki mescid (Beytülmakdis) olduğu iddiası sadece hadis kaynaklarında meşhur "şeddü'r-rihal (yolculuk)" hadisine dayandırılmaktadır. Bu hadisle ilgili Buhari ${ }^{48}$ ve Müslim'deki ${ }^{49}$ rivayetler Mescid-i Aksa olarak bitiyor, Müslim'de yine Ebu Hureyre'den nakledilen diğer bir hadiste ise Mescid-i İlya geçiyor ki, bununla Beytülmakdis'in kastedildiği açıktır.

Hadis metinlerinde üçüncü mescidin adının Mescid-i Aksa olduğu konusunda ittifak yoktur. İlk dönem tarih, coğrafya ve siret kaynaklarında yer alan "şeddü'r-rihal hadisinde üçüncü mescidin adı "Beytülmakdis" veya "ilya" olarak geçmektedir.

Yakubi, Tarihinde şöyle diyor: Abdullah b. Zübeyr'in, hacca gelenleri kendine biata zorlaması üzerine Emevi halifesi Abdulmelik b. Mervan (65-86/685-705) kendi bölgesindeki insanların hacca gitmelerini yasakladı. Bunun üzerine halktan "Üzerimize farz olan hac ibadetimizden bizi nasıl men edebilirsin"? itirazları üzerine "Bakın İbn Şihab ez-Zühri size rivayet ediyor ki: Üç mescidden başkası için yola çıkılmaz: Mescidü'1_Haram, benim mescidim ve Beytülmakdis mescidi. Bu sonuncusu sizin için Mescidü'l-Haram görevi yapsın. Resulullah'ın üzerine basarak göklere yükseldiği rivayet edilen bu kaya da sizin için Kabe görevi yapsın, diyerek bu kayanın üzerine bir kubbe bina etti. Halk, Kabeyi tavaf ettiği gibi bu kubbeyi tavaf etmeye başlad $1 .{ }^{50}$

Kubbetu's-Sahra'nın inşa tarihi (66-72/686-691), Abdullah b. Zubeyr'in ölüm tarihi (73/692) olduğuna göre bu uygulamanin en azından bir sene sürdüğü; Abdullah b. Zubeyr'in öldürülmesinden sonra buna son verildiği ve tekrar Mekke'ye haccedildiği anlaşılmaktadır. ${ }^{51}$

\footnotetext{
Buhari, Sahih, 1189.

Müslim, Sahih, 1397.

Yakubi, et-Tarih, c. I, s. 214; ed-Demiri, Hayatü'l-Hayevan el-Kübra, c. I, s. 100 ve c. II, s. 58

51 Zeyveli, Ilahi Dinlerde Mucize ve Gayb, ss. 78-80.
} 
(vi) Mescidu'l-Aksa Medine'dir.

Günümüzde bazı Müslüman alimler, İsra suresinin birinci ayetinin Medine' de nazil olduğu, bu ayetle Hz. Peygamber' in hicretine atıfta bulunulduğu ve "çevresi mübarek kılınan", "Allah'ın ayetlerinin yaşandığ1 ve gözlemlendiği" Mescidu'l-Aksa'nın bizzat "Medine Haremi" olduğu görüşünü benimsemiş bulunmaktadırlar. İki örnek olarak Ghulam Ahmad Parwez'in Exposition of the Quran' $1^{52}$ ile Ahmad Ali'nin The Quran'ın1 ${ }^{53}$ gösterebiliriz.

Aslında Medine'nin bir adının da "Mescidu'l-Aksa” olduğunu, meşhur Medine tarihçisi Semhudi, Vefä̈'l-vefa bi-Ahbari Dari'l-Mustafa isimli eserinde, dönemin meşhur Maliki alimlerinden Ahmed b. Abdirrahman et-Tadeli'nin (ö. 741/1341) bir eserine atfen nakletmektedir. ${ }^{54}$

İsra suresinin ilk ayeti hicretten bahsetmektedir; geleneksel İsra/Mirac rivayetleriyle ve dolayısıyla Kudüs'le veya Beytülmakdis'le alakası yoktur. İsra'nın veMescidü'l-Aksa'nın Kudüs ve Beytülmakdis'le ilişkilendirilmesi siyasi ve dini saiklerle Emeviler döneminde gerçekleşmiştir. Ancak böyle bir sonuca varmamız, Kudüs ve çevresinin Kur'an tarafından da mübarek görüldüğ̈ünün inkar1 anlamina gelmez (Kur'an 7/137; 21/71,81; 34/18). ${ }^{55}$

(vii) Mescid-i Aksa Kudüs'tür.

İsra suresinde söz konusu edilen "el-Mescidu'l-Aksa"nın Kudüs olduğunu savunanlar ise şu gerekçeleri ileri sürmektedirler:

- En yakın bölgede en uzak mescid olabilir. Bizans ile İran'ın savaştığ1 ve Bizans'ın yenildiği Filistin bölgesi Kur'an'da Hicaz'a en yakın bölge diye nitelenmektedir. Geniş perspektifte Hicaz'a yakın olan Filistin coğrafyasında pek ala en uzak mescid olabilir.

- O dönemde Kudüs'teki Harem-i Şerif denilen bölgede illa da bir yapının olması şart değildir. Zaten tarihen sabittir ki İsra mucizesi günlerinde orada bir yapı yoktur. Tarihi bilgilerimize göre $\mathrm{Hz}$. Süleyman tarafından yedi yıllık bir inşaattan sonra MÖ 960 yılında hizmete açılan Beit ha-Mikdaş/Beytülmakdis, MÖ 587'de Babil Kralı Nebukadnezar tarafından yıkılmış, MÖ 515'te ikinci kez yapılan

52 Ghulam Ahmad Parwez'in Exposition of the Quran adlı eseri aşağıdaki linkten indirilebilir. http://islamicdawn.com/wp-content/uploads/2014/10/eohq.pdf.

53 Ahmad Ali, The Qur'an, s. 249.

54 es-Semhudi, Vefau'l-vefa, c. I, s. 26

55 Zeyveli, İlahi Dinlerde Mucize ve Gayb, ss. 81-84. 
mabed, MÖ 20'li yıllarda Hirodes tarafından genişletilerek yenilenmiş, MS 70 yılında Roma ordu komutanı (sonradan imparator olan) Titus tarafından ikinci ve son kez yıkılmış, mabedin yerine İmparator Hadrianus tarafından, MS 136 yılında Roma ilahı Jupitere ithafen bir pagan tapınak yaptırılmış (Colonia Aelia Capitolina), bu pagan tapınak da, Roma'nın Hıristiyanlığı benimsemesi üzerine y1kılmış, İsa Mesih'in "Bu yapıda taş üstünde taş kalmayacaktır" (Matta, 24/2) sözüne ittibaen yeni bir mabed yapılmamıştır. Dolayısıyla Emeviler tarafından orada Kubbetu's-Sahra ve Mescid-i Aksa yapilıncaya kadar bir yapı yoktur.

BeytulMakdis, öncelikle bir yapı ancak yapının kurulduğu alan (Harem-i Şerif) ve şehrin bizatihi kendisidir. Nasıl ki el-Mescidü'l Haram, bir binanın/yapının değil, bir alanın adı olup bu isimle bütün "Mekke Haremi" kastedilmekte ise, "el-Mescidu'l-Aksa da Allah'a kulluk edilen başka bir alanın adı olmaktadır.

Özellikle İsrâ hadisesinden sonra sahabiler, bu mukaddes beldeye yoğun ilgi göstermiş, Hz. Peygamber (sav)'in vefatı sonrasında ise Kudüs'ü fethetmeyi amaçlamışlardır. Çünkü Resûlullah, vefatından hemen önce Beytülmakdis'in yakında fethedileceğini müjdelemiş hatta Şam/Filistin topraklarına gönderilmek üzere Üsâme b. Zeyd komutasında bir ordu hazırlatmıştır. Bu sebeple sahabiler Allah Resûlü'nün vefatının hemen ardından Kudüs topraklarını fethe yönelmişlerdir. Filistin bölgesinin önemli bir kısmı, Hz. Ebû Bekir döneminden itibaren Müslümanların hâkimiyetine girmiştir. Hz. Ebû Bekir'in Filistin cephesi komutanı Amr b. el-Âs, başta Gazze ve Nablus olmak üzere birçok kenti Hıristiyan Bizans'tan alarak İslam topraklarına katmış ve Kudüs önlerine kadar gelmiştir.

Hz. Ebû Bekir döneminde ilk fethedilmesi gereken yerlerden biri olarak görülen Kudüs, nihayet Hz. Ömer döneminde (17/638) yılında Ebu Ubeyde b. Cerrâh komutasındaki İslâm askerlerinin gayretleriyle Bizanslılardan teslim alınmış ve İslâm topraklarına dâhil edilmiştir. Ayrıca Hz. Peygamber döneminden itibaren bazı sahabiler ibadet ve ziyaret maksadıyla Mescid-i Aksâ'ya özel yolculuklar yapmışlardır. Bu bilgiler ışığında Kudüs'ün, Mekke döneminden itibaren sahabenin ilgi odağı haline geldiğini, onların gözünde ve gönlünde bu toprakların müstesna bir yere sahip olduğunu ifade etmek mümkündür. Denilebilir ki Hz. Ömer zamanında gerçekleşecek olan Kudüs fethinin hikâyesi, Müslümanların namaz- 
larını Beytülmakdis'e yönelerek kıldıkları andan itibaren başlamıştır. Binaenaleyh sahabenin henüz fethedilmeden önce Kudüs'e ve Mescid-i Aksâ'ya hususi ilgi gösterdiği sarahaten anlaşılmaktadır. Bu ilginin sebeplerini ise şu şekilde sıralamak mümkündür:

- Kudüs topraklarının faziletini bildiren ayetler, sahabenin dikkatini bu topraklar üzerine çekmiştir. Kur'an-1 Kerim'de, Kudüs topraklarının faziletine dair birçok ayet vardır. Bu ayetlerden beş tanesi Kudüs topraklarının bereketli kılındığını ifade ederken, biri de bu toprakları "el-arzu'l-mukaddese" olarak nitelemektedir. Bu iki vasfı kullanmaksızın Kudüs'e işaret eden daha başka ayetler de vardir.

- Kudüs'ün en önemli özelliği Peygamberlik yurdu olmasıdır. Çok sayıda peygamberin yaşadığı mukaddes bir mekân olması ve peygamberlerden miras kalan Beytülmakdis'i içerisinde barındırması açısından da Kudüs, sahabenin gözünde önemli bir yere sahip olmuştur.

- Sahabenin Kudüs'e gösterdiği ilginin sebeplerinden biri de Mescid-i Aksâ'nın etrafının mübarek kılınması ve bu mescidin, Allah'ın yeryüzündeki ilahi ayetlerinden bir kısmını bünyesinde veya çevresinde barındırmasıdır. Dolayısıyla, Mescid-i Aksâ sıradan bir mekân değil içerisinde veya çevresinde bir kısım harikaları barındıran mübarek bir mescittir. Âyet-i kerimede şöyle buyrulmaktadır: “Kulunu, kendisine birtakım ayetlerimizi göstermemiz için bir gece Mescid-i Harâm'dan çevresini mübarek kıldığımız Mescidi Aksâ'ya yürütenin şanı pek yücedir. Şüphesiz o her şeyi işitendir, görendir." (İsra 17/1). Yusuf el-Karadâvî'nin de belirttiği gibi Kur'ân, Mescid-i Aksâ'nın önem ve bereketini Mescid-i Nebevî inşa edilmeden ve hatta hicretten birkaç sene önce ilan etmiştir. Hadis-i şeriflerle de Kur'ân'ın ilan ettiği bu husus teyit edilmiştir.

- Mescid-i Aksâ'nın Mescid-i Harâm'dan sonra yeryüzünde inşa edilen ikinci mescid olması, sahabenin Kudüs topraklarına önem vermesinin sebepleri arasında zikredilebilir.

- Bilindiği üzere Kudüs, Müslümanların ilk kıblesidir. Kıble Kâbe'ye döndürülmeden önce Müslümanlar, namazlarını belli bir müddet Beytülmakdis'e yönelerek kılmışlardır. Bu durum sahabenin dikkatini bir dönem oraya tevcih etmiş ve Müslümanların bu şehri dinî bir merkez olarak görmelerinin sebeplerinden birini teşkil etmiş̧ir. Müslümanlara yüzlerini Mescid-i Haram'a çevirmelerini 
emreden Kur'ân ayetleri ininceye kadar Kudüs, Müslümanların kıblesi olmaya devam etmiştir.

- İsrâ ve Mi'râc hadisesi Kudüs'ün kıymetini sahabe gözünde bir kat daha artırmıştır. Resûlullah (sav) hicretten önce İsrâ suresinin birinci ayetinde de zikredildiği gibi bir gece Mescid-i Harâm'dan çevresi mübarek kılınan Mescidi Aksâ'ya yürütülmüştür. Allah Resûlü (sav) Cibril ile birlikte Beytülmakdis'e girmiş ve orada iki rekat namaz kılmıştır. Yüce Allah, yeryüzünde gerçekleşen İsrâ yolculuğunun bitiş ve gökyüzünde gerçekleşen Mirâc yolculuğunun başlangıç noktası olarak Kudüs'ü seçmiştir. ${ }^{56}$

\section{Sonuç}

Kudüs, Yahudiler ve Hıristiyanlar için kutsal olduğu gibi Müslümanlar için de kutsaldır. Şehir adı olarak Kudüs, her ne kadar Kur'an'da geçmiyorsa da, İsra mucizesi dolayısıyla Kur'an'da yer alan el-Mescidü'l-Aksa'nın Kudüs'teki Süleyman Mabedi, dolay1sıyla Kudüs olduğu kabul edilmektedir. Zira Kudüs şehrine, içinde barındırdığı Mabedin kutsiyetine binaen Mescid-i Aksa denildiği tarihen sabittir.

Bugün Kudüs'teki Harem-i Şerif diye adlandırılan mekanda Emevi halifesi Abdülmelik b. Mervan tarafından yaptırılan Kubbetü's-Sahra ve oğlu I. Velid tarafından yaptırılan Mescid-i Aksa bulunmaktadır. Kubbetü's-Sahra, Hacer-i Muallak denilen ve Peygamberimizin üzerine basarak semaya yükseldiği kabul edilen kaya kütlesini örtmektedir.

Kur'an-1 Kerim'de Mescid-i Aksa'nın çevresinin mübarek kılındığ 1 belirtilmektedir. Çevresi mübarek kılınan bu mescid ve şehir, yine Kur'an'da "Mukaddes Belde" diye nitelenen (el-Maide 5/21) Arz-1 Mev'ud'un içindedir. Diğer taraftan Kudüs'ü ilk defa fetheden $\mathrm{Hz}$. Davud ve orada Beytülmakdis'i inşa eden Hz. Süleyman, İslam inancına göre kendilerinde nübüvvet ve hükümdarlık cem edilmiş olan peygamberlerdir.

56 İsmail Altun, "Sahabe Gözünde Kudüs ve Mescid-i Aksa", İlahiyat Tetkikleri Dergisi, 2017, say1: 47, ss.157-162. 


\section{Kaynakça}

Abdürrezzak. el-Musannef, c. I. III, VIII

Ahmed b. Hanbel. Müsned, thk.: Şu'ayb Arnavut-Adil Mürşid, (Beyrut, 1995), c. I, V.

Ali, Ahmad. The Qur'an, (USA: Princeton University Press, 1988).

Altun, İsmail. "Sahabe Gözünde Kudüs ve Mescid-i Aksa", İlahiyat Tetkikleri Dergisi, 2017, sayı: 47, ss.157-162.

Azimli, Mehmet. "İsra ve Mirac Olayları Üzerine Bazı Mülahazalar", Bilimname, , 2009, say1: XVI /1, ss. 43-58.

Balcı, İsrafil. İsra ve Mirac Gerçeği, (Ankara 2012).

Belazuri. Ensabu'l-Eşraf, (Dımeşk 1997), c. I.

Bozkurt, Nebi. "Mescid-i Aksa", DIA, XXIX.

Buhari. Sahih c. I, (Enbiya; Savm; Sayd).

ed-Demiri. Hayatü'l-Hayevan el-Kübra, c. I, II.

Ebu Şehbe. Sünnet Müdafaası, çev.: M. Görmez, M. Emin Özafşar, (Ankara 1990), c. II.

Elmalılı, M. Hamdi. Hak Dini Kur'an Dili, c. IV.

Ezrak. Ahbaru Mekke, c. II.

Goldziher, Ignaz. Muslim Studies, c. II.

Hamidullah, Muhammed. İslam Peygamberi, c. I.

İbn Kesir. el-Bidaye ve'n-Nihaye, (Beyrut, 2005), c. II.

el-Khatib, Abdallah. " Jerusalem in the Qur'an", British Journal of MiddleEastern Studies, 2001, sayı: 28/1.

Malik b. Enes. Muvatta, thk.: Muhammed Mustafa el-A'zamî, (yy, 2004), c.I.

Esed, Muhammed. Kur'an Mesajı, (İstanbul 2001).

Müslim. Sahih, Mesacid 1,2; “Hac”, 415, 511, 512.

Nesâî. Mesâcid, 3, 10.

Örenç, Aşır. “Kudüs ve Mescid-i Aksa'nın Faziletine Dair Hadisler ve Yorumu", Türk-İslam Medeniyeti Akademik Araştırmalar Dergisi, 2016, say1: 22, ss.133-150.

es-Semhudi. Vefau'l-vefa, c. 1.

Taberi. Tarihu'l-ümem ve'l-müluk, (Beyrut 1995), c. 1.

Taberi. Câmiu'l-beyân, c. 6, 16.

Vakıdi. Kitabü'l-meğazi, c. 3.

Wensinck, A. J. "Mescidi Aksa”, İA, c. 8.

Yakubi, et-Tarih, c. 1-2.

Yaşaroğlu, K. "İsra Suresi”, DİA, (Ankara: TDV Yayınları, 2001), c. 23/ 177.

Yücel, Ahmed. Oryantalist Hadis Anlayışı ve Eleştirisi, (İstanbul, 2015).

Zeyveli, Hikmet. İlahi Dinlerde Mucize ve Gayb, (İstanbul, 2018). 